\title{
PEMBERDAYAAN PEMBUATAN NATA DECOCO BAHAN LIMBAH AIR KELAPA PADA FATAYAT NU METRO
}

\author{
Annikmah Farida ${ }^{1}$, Rita Rahmawati ${ }^{2}$, Habib Shulton Asnawi ${ }^{3}$, \& Andika Ari Saputra ${ }^{4}$ \\ 1,2,3,4 Institut Agama Islam Ma'arif NU Metro Lampung \\ faridaannikmah@gmail.com, ritarahmawati1777@yahoo.co.id, habibshulton1708@gmail.com, \\ andika@iaimnumetrolampung.ac.id
}

\begin{abstract}
The purpose of this community empowerment guidance in to utilize overcome the problem of environmental pollution of coconut water waste into useful economical processing in the form of nata decoco for members of Fatayat NU, Metro Utara District, Metro City so that coconut water has not been ignored by coconut traders. In the traditional markets in Metro Utara District and its surroundings, it can be utilized. The method used in community empowerment uses the Asset Based Community Development (ABCD) mentoring approach. The number of participants who attended was 20 people consisting of the Fatayat NU Management Branch of the Metro City, the Executive of the Fatayat NU Branch of the North Metro District and the Fatayat NU Management, the North Metro District. The result of this empowerment is having skills in processing coconut water waste into a useful and economical process so that it can increase family income.
\end{abstract}

Keywords: Coconut Water Waste, Nata Decoco, Training

\begin{abstract}
$\overline{\text { ABSTRAK : Tujuan dari pendanpingan pemberdayaan masyarakat ini adalah ntuk pemanfaatan dan }}$ mengatasi masalah pencemaran lingkungan limbah air kelapa menjadi olahan yang bermnanfaat dan bernilai ekonomis dalam bentuk nata decoco untuk para anggota Fatayat NU Kecamatan Metro Utara Kota Metro sehingga air kelapa yang selama ini tidak dimafatkan oleh para pedagang kelapa dipasar-pasar tradisisonal yang ada di Kecamatan Metro Utara dan sekitarnya bisa dirmanfaatkan. Metode yang digunakan dalam pemberdayaan masyarakat ini menggunakan pendekatan pendampingan Asset Based Community Development (ABCD). Adapun jumlah peserta yang hadir 20 orang terdiri dari Pengurus Fatayat NU Cabang Kota Metro, Pengurus Fatayat NU Anak Cabang Kecamatan Metro Utara dan Pengurus Fatayat NU Ranting Kecamatan Metro Utara. Hasil dari pemberdayaan ini adalah memiliki ketrampilan dalam pengolahan limbah air kelapa menjadi suatu olahan yang bermnafaat dan bernilai ekonomis sehingga penambah pendapatan bagi keluarga.
\end{abstract}

Kata Kunci: Limbah Air Kelapa, Nata Decoco, Pelatihan

\section{PENDAHULUAN}

Pohon kelapa adalah salah satu jenis tanaman yang tumbuh subur di Negara Indonesia karena pohon kelapa sangat cocok dengan iklim yang ada diIndonesia, Tanpa perawatan yang khusus pohon kelapa bisa tumbuh subur dimana saja. Pohon kelapa ini memiki manfaat yang sangat banyak mulai dari daunnya, batang pohon sampai buah yang dihasilkan. Manfaat dari buah kelapa sangatlah banyak, Diantaramya adalah airnya untuk menghilangkan dahaga, daging buah kelapa yang masih muda dapat dibuat sebagai campuran minuman atau makanan sedangkan daing buah yang sudah tua dapat dibuat sebgai 
santan kelapa sebagai bahan campurn dalam membuat makanan atau minuman.

Air kelapa memiliki banyak kandungan mineral antara lain natrium $(\mathrm{Na})$, kalsium (Ca), Magnesium ( $\mathrm{Mg}$ ), Ferum (Fe), Cuprum $(\mathrm{Cu})$, Pospor $(\mathrm{P})$, dan Sulfur (S). selain mineral air kelapa juga mengandung gula antara 1,7-2,6 gram, protein 0,07-0,55 $\%$,dan mengandung berbagai macam vitamin seperti asam sitrat asam nikotina, asam pantotenal, asam folat,niacin, riboplavin, thiamin, mengandung hormone auksin dan sitokinin. ${ }^{1}$

Nata de coco merupakan produk yang dihasilkan dari proses fermentasi air kelapa. Menurut asal-usulnya, nata de coco pertama kali dikenal oleh orang Filipina. Meski demikian, nama nata de coco sendiri bukan berasal dari bahasa Tagalog, bahasa resmi negara Filipina. Nata de coco berasal dari dari bahasa Latin, yang merupakan bahasa ibu orang Spanyol. Hal ini tidak mengherankan, karena Filipina sendiri merupakan koloni Spanyol. Dalam bahasa Latin, kata "nata" memiliki arti "krim", yang berasal dari kata "natare" yang berarti terapung-apung. Sedangkan "coco" sendiri artinya adalah "buah kelapa". Jadi, berdasarkan asal katanya,

${ }^{1}$ Lucia C Mandey, Jenny E A Kandou, dan Tineke M Langi, "Pengembangan Produksi Selulosa Nata Sebagai Produk Kesehatan dari Limbah Air Kelapa dengan Menggunakan Bakteri Acetobacter xylinum" 4, no. 2 (2016): 8. "nata de coco" memilki arti "krim dari buah kelapa". ${ }^{2}$

Air kelapa muda lebih banyak mengandung air, sehingga proses penggumpalan membentuk nata menjadi lebih sulit. Pemanfaatan limbah pengolahan kelapa berupa air kelapa merupakan cara mengoptimalkan pemanfaatan buah kelapa. Limbah air kelapa cukup baik digunakan untuk substrat pembuatan Nata de Coco. Ini di dukung dengan ketersediaan air kelapa yang berlimpah di Indonesia. Di Negara Indonesia Kelapa merupakan salah satu komoditas unggulan di Indonesia. Mengingat ketesediaan bahan baku kelapa dan permintaan konsumsi masyarakat akan buah kelapa semakin meningkat, maka bisnis produksi dengan bahan baku kelapa merupakan bisnis yang sangat prospektif.

Penelitian dan riset telah memberikan terobosan-terobosan penting untuk memaksimalkan fungsi dan pemberdayagunaan tidak hanya buah kelapa saja tetapi sudah dapat memanfaatkan semua unsur kelapa yang salah satunya adalah air kelapa. Nutrisi yang terkandung dalam air kelapa antara lain : karbohidrat, protein, lemak, kalsium, fosfor, zat besi, vitamin $\mathrm{B}$ kompleks, riboflavin, potassium, dan lainnya. Adanya gula sukrosa dalam air kelapa akan dimanfaatkan oleh bakteri Acetobacter xylinum sebagai sumber energi, maupun sumber karbon untuk membentuk senyawa

${ }^{2}$ Nurhasanah dkk., "Pelatihan Pembuatan Nata de Coco Secara Higienis bagi Masyarakat Desa Fajar Baru Lampung Selatan" (Lampung: Universitas Lampung, 2017). 
metabolit diantaranya adalah selulosa yang membentuk Nata de Coco. Senyawa peningkat pertumbuhan mikroba (growth promoting factor) akan meningkatkan pertumbuhan mikroba, sedangkan adanya mineral dalam substrat akan membantu meningkatkan aktifitas enzim kinase dalam metabolisme di dalam sel A. xylinum untuk menghasilkan Selulosa.

Akan tetapi pada realitanya masyarakat belum banyak tahu akan manfaat air kelapa sehingga air kelapa yang begitu banyak kandungan gizinya hanya terbuang sebagai limbah . Ada banyak faktor yang menyebabkan kurangnya minat masyarakat untuk memanfaatkan limbah air kelapa antara lain karena terbatasnya pengetahuan masayrakat.

Banyaknya limbah air kelapa dikarenakan di masyarakat banyak membutuhkan daging kelapa yang sudah tua untuk dijadikan sebgai santan sebagai bahan tambahan dalam masakan dan digunakan sebagai bahan baku pembuatan minyak goreng .Disamping itu adanya beberapa pengelola usaha home industri kopra yang bahan dasarnya adalah buah kelapa yang sudah tua ,dari beberapa pemnafaatan buah kelapa air kelapa tidak dimanfaatkan sehingga menjadi terbuang dan menjadi limbah.

Salah satu olahan limbah dari air kelapa adalah dengan dibuat sebagai nata decoco. Untuk Mengatasi masalah pencemaran lingkungan karena air kelapa dan sekaligus meningkatkan nilai ekonomi dari limbah air kelapa maka air kelapa ini dapat dimanfaatkan untuk dijadikan berbagai produk diantaranya adalah dengan membuat Nata de coco.

Nata decoco adalah salah satu makanan yang dalam proses pembuatannya terbentuk dari jutaan benang selulosa yang berlapis-lapis sehingga baik untuk dikonsumsi karena mengandung banyak gizi dan serat yang sangat dibtuhkan oleh pencernaan tubuh kita. ${ }^{3}$ Akan tetapi akhir-akhir ini muncul beberpa pemberitaan yang menyebutkan bahwa nata decoco yang banyak dijual dipasaran berbahya bagi anak-anak dan orang dewasa yang mengkonsumsinya karena menyerupai plastik atau kertas sehingga tidak bisa dicerna oleh tubuh kita dan pastinya karena tidak mudah dicerna oleh pencernaan kita maka akan sangat berbahaya bagi kesehatan. $^{4}$

Kota Metro adalah salah satu kota yang memiliki banyak pasar tradisional disetiap wilayah kecamatan. banyak sekali para pedagang kelapa yang tidak memanfaatkan limbah air kelapa. Kebayakan air kelapa hanya dibuang begitu saja jika tidak

\footnotetext{
3“Kompas.com," Viral Nata De Coco Mengandung Plastik, Ini Penjelasan BPOM (blog), t.t., https://sains.kompas.com/read/2019/12/08/1904001 23/viral-nata-de-coco-mengandung-plastik-inikata-badan-pom 4"Tempo.co," Viral Nata De Coco Mengandung Plastik, Ini Penjelasan BPOM (blog), t.t., https://bisnis.tempo.co/read/1281619/viralnata-de-coco-mengandung-plastik-ini-penjelasanbpom.
} 
ada pembeli yang membutuhkan air kelapa tersebut sedangkan jumlah kelapa yang dijual setiap harinya cukup banyak sedangkan Air kelapa memiliki kandungan gizi yang cukup tinggi.

Dengan memberikan pengetahuan dan ketrampilan cara mengolah limbah air kelapa menjadi nata de coco kepada anggota Fatayat NU Kecamtan Metro Utara Kota Metro yang semua anggotanya adalah perempuan dan sebagian besar adalah ibu-ibu Rumah Tangga yang masih muda dan produktifsehingga mereka bisa mengolah limbah air kelapa menjadi olahan bahan minuman atau makanan yang bernilai ekonomis dari nata de coco dan membantu mengatasi pencemaran lingkungan dari air limbah kelapa yang selama ini hanya dibuang begiru saja .

Seperti halnya pengabdian masyarakat yang pernah di lakukan oleh Muammad Alkadri Perdana ,Hutomo Atman Maulana (2019), menjelaskan bahwa limbah air kelapa yang selama ini tidak dimanfaatkan oleh para petani kelapa di Desa Bantan Sari Kecamatan Bantan diedukasi dengan pelatian seingga air kelapa yang selama ini hanya menjadi limbah dapat di manfaatkan menjadi nata de coco. (Muammad Alkadri Perdana ,Hutomo Atman Maulana ,2019), Mulyono Aprianto melakukan pendamppigan kepada kelompok Tani Sinar Bahagia yang tidak mengetahui diversifikasi komodii kelapa, pendapatan petani kelapa yang rendah, tidak mengetahui pemasaran produk dan memiliki sikaapyang pasrah terhadap keadaan, sedangkan permasalahan yang dihadapi oleh mitra kedua yaitu Kelompok PKK Desa Pasir Mas adalah kurangnya kegiatan produktif dan tidakengetahui cara pemasaran produk.Dari persoalan tersebut sepakat untuk mengolah bagian kelapa yang selama ini di buang begitu saja (air kelapa) padahal dapat diproduksi menjadi produk turunan yang bernilai ekonomi yaitu nata de coco. (Mulyono Aprianto,2019).

\section{METODE PELAKSANAAN}

Pengabdian ini menggunakan pendekatan pendampingan Asset Based Community Development (ABCD). Langkah-langkah pengabdian kepada masyarakat dengan menggunakan pendekatan $\mathrm{ABCD}$ adalah:

\section{Discovery/Menemukan,Proses} menemukan (discovery) dilakukan melalui teknik observasi dan wawancara dengan beberapa pedagang kelapa di pasar Kota Metro dan mengamati lingkungan beberapa pasar yang ada di Kota Metro seperti pasar Kota Metro (Mega Mall Kota Metro) ,Pasar Pagi Kota Metro, Pasar Cendrawasih ,Pasar 24 dan Pasar Margorejo Metro Selatan ,Pasar Pagi Metro Utara dan lain lain.

Dari wawancara tersebut didapatkan pengetahuan tentang aset dan potensi yang ada yaitu para anggota Fatayat dan Muslimat Kota Metro para pedagang kelapa dipasar-pasar Kota 
Metro dan sekitarnya dan sumber daya alam yaitu air kelapa dari para pedagang kelapa .

2. Dream/ impian, Para anggota Fatayat dan Muslimat Kota Metro diharapkan dapat memiliki ketrampilan, mengolah air kelapa sehingga air kelapa yang selama ini hanya di buang oleh para pedagang kelapa tidak lagi menjai sebuah persolan tetapi bisa lebih bermanfaat dan memiliki nilai ekonomis.

3. Design /Merancang, Proses merancang adalah langkah merencanakan mimpimimpi yang diharapakn oleh para anggota Fatayat dan Muslimat Kota Metro

4. Define/Menentukan, Pada tahapan ini bertujuan untuk mendesain kegiatan yang akan dilakukan yaitu memberikan pelatihan ketrampilan dalam mengelola bahan limbah air kelapa menjadi suatu olahan yang bermanfaat dan bernilai ekonomis.

Pada tahap ini juga dilakukan Focus Group Discussion (FGD).FGD dengan para narasumber dan Pengurus PAC Fatayat NU Kecamatan Metro dan PAC Fatayat NU Kota Metro

Destiny/Melakukan, Langkah yang terakhir adalah tahap pelaksanaan kegiatan yang sudah disepakati untuk memenuhi impian masyarakat dari pemanfaatan asset. Prosedur pelaksanaan kegiatan dibagi menjadi tiga tahap yaitu.Tahap persiapan, tahap pelaksanaan, dan tahap akhir.

\section{HASIL DAN PEMBAHASAN}

1. Bahan yang digunakan

Bahan yang digunakan pada pembuatan nata de coco terdiri dari bahan baku dan bahan bantu. Bahan baku yang digunakan berupa air kelapa. Sedangkan bahan bantu berupa asam cuka, urea, gula dan stater/bibit nata. Adapun fungsi dari bahan bantu masing-masing, sebagai berikut :

a. Asam asetat (asam cuka)

Penggunaan asam asetat pekat $(99,8 \%)$ dimaksudkan untuk menurunkan $\mathrm{pH}$ sampai 3- 4 tanpa banyak menambah volume. Menggunakan asam asetat pekat harus hati-hati, karena dapat mengeluarkan bau yang menyengat, bahaya kalau tertelan, menetes dikulit dan terpercik di mata.

b. Urea

Penggunaan urea dalam pembuatan nata de coco adalah sebagai sumber nitrogen yang akan merangsang pertumbuhan dan aktivitas bakteri Acetobacter xylinum.

c. Gula

Gula dalam pembuatan nata de coco berfungsi sebagai sumber karbon atau energi. Semua jenis gula bisa digunakan sebagai 
sumber karbon baik itu glukosa, sukrosa, maupun maltose.

d. Stater/bibit

Stater/bibit yang digunakan adalah bakteri Acetobacter xylinum. Bakteri ini mampu membentuk suatu lapisan yang dapat mencapai ketebalan beberapa sentimeter. Bakteri terperangkap dalam benang - benang yang dibuatnya. Untuk menghasilkan massa yang kokoh, kenyal, tebal, putih, dan tembus pandang perlu diperhatikan suhu fermentasi (inkubasi), komposisi medium dan $\mathrm{pH}$ medium.

2. Proses Pembuatan Lembaran Nata

a. Air kelapa mentah di saring, kemudian diukur volumenya sebanyak 10 liter dan dimasukkan ke dalam dandang/panci ukuran 10 liter/kg di masak sampai mendidih 100 derajat celcius, setelah mendidih masukkan gula pasir, za, dan cuka diaduk hingga rata, masak kira-kira 5 menit dari saat air kelapa mendidih.

b. Masukan ke dalam baki plastik kira 1,2 liter dan harus dipastikan bahwa baki plastik dalam kondisi bersih dan steril dari bakteri.

c. Baki plastik ditutup dengan menggunakan koran dan pastikan koran pun dalam kondisi steril dari bakteri yang akan mengganggu pertumbuhan nata de coco/sari kelapa, koran harus dijemur dipanas matahari.

d. Baki-baki ditutup rapat dan disusun di atas rak baki secara rapi dan ditiriskan sampai dingin untuk diberi bibit nata de coco

e. Baki baki yang sudah didisi dengan air kelapa dan ditutup dengan Koran disimpan dalam sebuah ruangan tertutup yang sebelumnya sudah distrrilkan terlebih dahulu . baki-baki ini tidak boleh terkena sinar matahari selam kurang lebih 7 hari.

3. Proses Pemberian Bibit Nata de coco, Baki baki yang berisi air kelapa yang sudah diinapkan selama satu malam dibuka sedikit untuk di masukkan bibit nata yang sudah dipersiapkan. Setelah itu bibit nata dimasukkan kedalamnya kemudian dittup kembali untuk difermentasikan selama kurang lebih 6 hari . Selama proses fermentasi ruangan setiap hari harus disemprot degan air c uka untuk mensetrilkan ruanagan sehingga proses fermentasi air kelapa menjadi nata de coco bisa berjalan dengan baik .Baki hasil pembibitan tidak boleh terganggu apapun, tidak digoyang-goyang, bila ingin melihat hasil nata de coco bisa dilihat pada hari ke 3 .

4. Proses melihat hasil fermentasi Setelah difermentasi selama kurang ebih 4 hari . Setelah baki-baki tersebut 


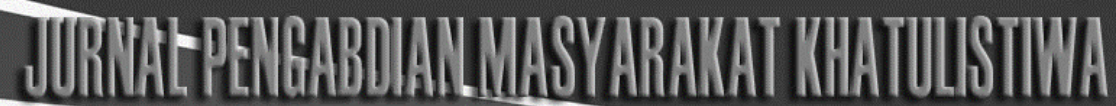

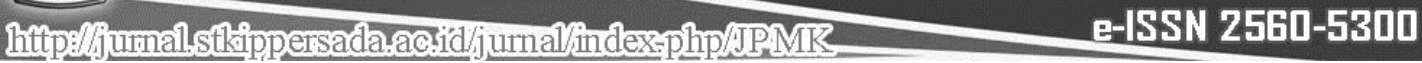

dibuka sedikit dan dilihat hasilnya dalam baki-baki yang berinsi air kelapa sudah mulai muncul benangbenang putih sebagai tanda bahwa proses fermentasi air kelapa menjadi nata de coco sudah nampak , kemudian baki-baki tersebut ditutup kembali dan dilanjtkan proses fermentasinya kurang lebih menjadi 7 hari . Jika pembuatan nata de coco berhasil maka air kelapa yang sudah difermentasi akan berubah menjadi lembaran-lembaran putih nata yang siap untuk dipanen.

5. Hasil Akhir Proses Lembaran Nata De Coco

Setelah melalui proses perendaman selama kurang lebih 7 hari maka nata sudah bisa diproses untuk dijadikan makanan. Nata yang sudah direndam selama kurang lebh 7 hari dicuci bersih dan ditiriskan kemudian direbus dengan air mendidih kurang lebih 15 menit . setelah itu direbus dalam panic yang berisi air gula dan daun pandan kurang lebih 30 menit .Setelah direbus dalam air gula nata de coco siap untuk dikemas dalam plastik atau bisa disajikan langsung sebagai minuman ,bahan tambahan dalam pembuatan es buah ,kolak, pudding dan lain-lain.

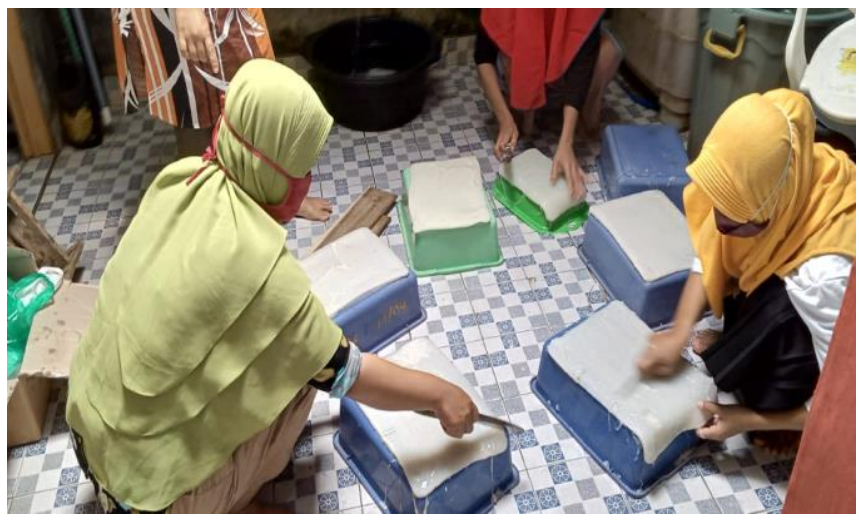

Proses pemanenan nata

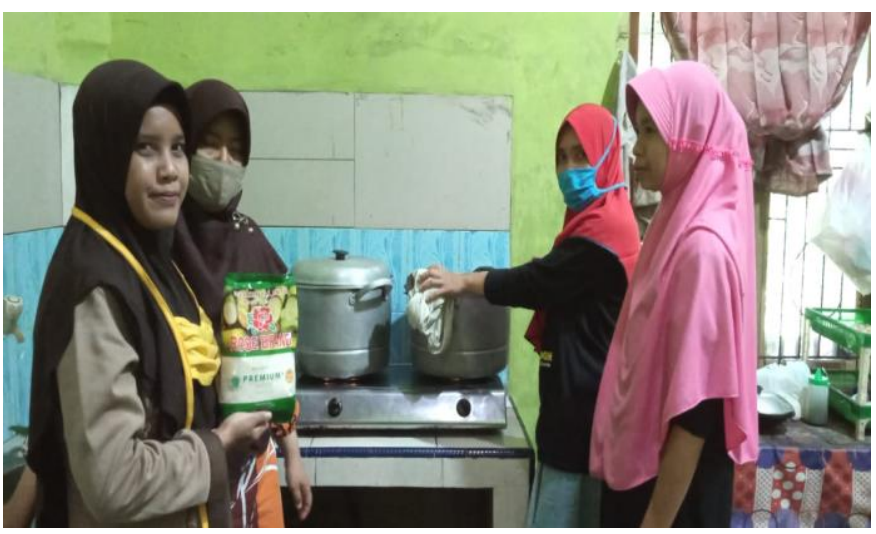

Proses Perebusan Nata

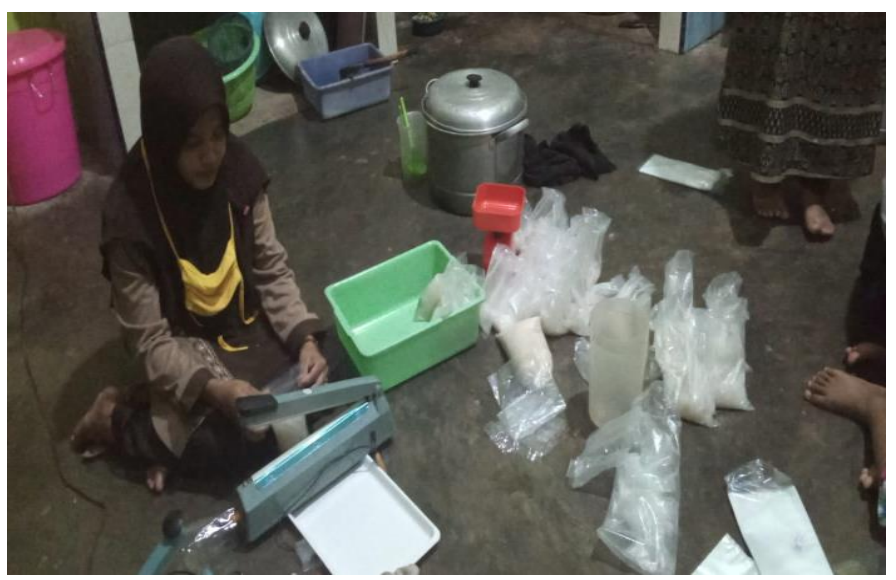

Proses Pengemasan 


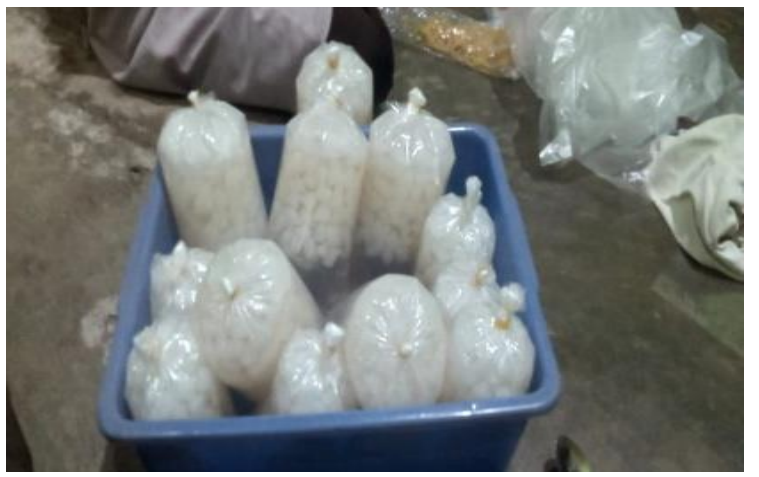

Hasil Akhir Nata de Coco

\section{Proses Pembuatan Manisan Nata :}

1. Nata lembaran dibersihkan dari lender, kemudian dilakukan perendaman selama 2 hari, setiap hari air harus diganti.

2. Pencucian I, menggunakan air bersih

3. Pemotongan nata (bentuk kubus $1 \times 1 \times 1$ cm3) menggunakan pisau yang tajam atau mesin pemotong.

4. Perendaman I, nata yang sudah dipotong direndam selama satu malam

5. Pencucian II, menggunakan air bersih

6. Perebusan I sampai mendidih selama 30 menit kemudian ditiriskan.

7. Peremdaman II dengan air bersih dan dibiarkan selama semalam

8. Pencucian III, menggunakan air bersih

9. Perebusan II sampai mendidih selama 30 menit kemudian ditiriskan

10. Perebusan dengan gula selama 30 menit api kecil dan sering diaduk supaya tidak gosong.

11. Tiriskan dan siap dilakukan pengemasan

\section{Pembuatan Air Gula}

1. Didihkan air sebanyak 20 liter didalam panic

2. Setelah mendidih masukkan gula pasir $3 \mathrm{~kg}$, garam $20 \mathrm{gr}$, asam benzoate $1 / 4$ sdm, asam sitrat $1 / 4 \mathrm{sdm}$, dan vanili/perisa

3. Aduk hingga rata dan siap dikemas

4. Pengemasan dilakukan dengan menimbang nata sebanyak 375 gr, kemudian ditambahkan air gula hingga volumenya mencapai I liter 
Prosedur Pemanisan Nata de Coco dapat dilihat pada bagan dibawah ini $^{5}$

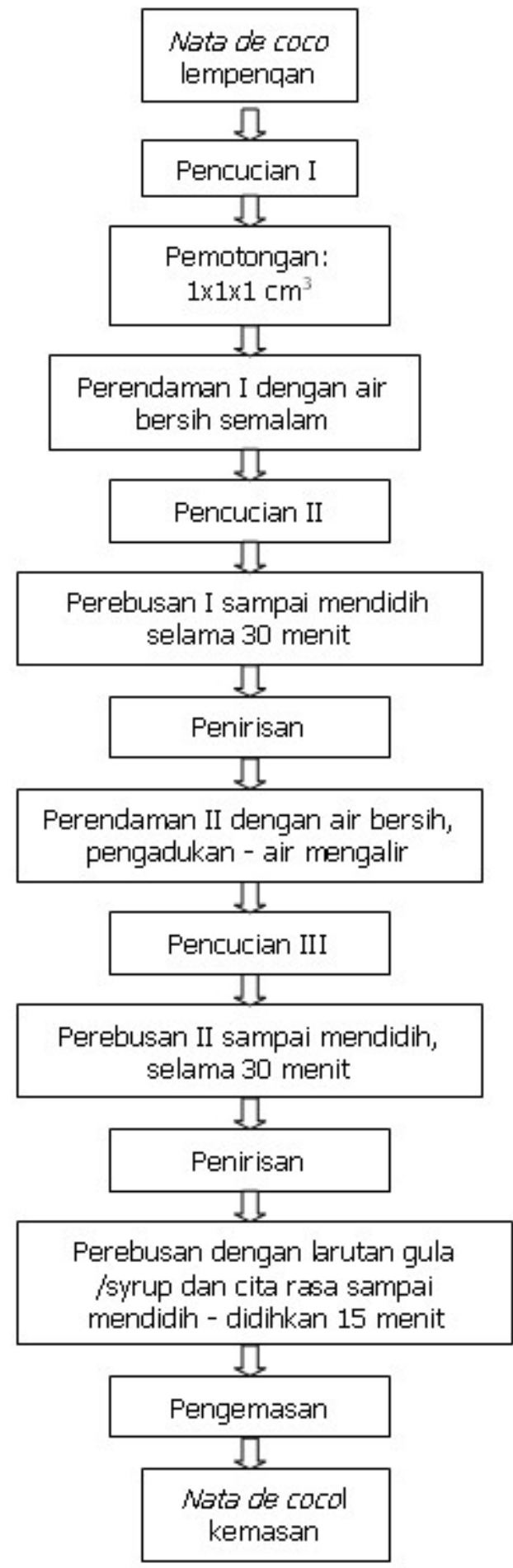

5"Tempo.co."
Diskusi Praktik pembuatan nata de cocobagi anggotaFatayat NU Kecamatan Metro Utara dapat menambah ketrampilan bagi anggota darinyang sebelumnya tidak mengetahui pemaanfaatan limbah air kelapa menjadi nata de coco . Dengan bertambahnya pengetahuan dan ketrampilan ini para anggota Fatayat dapat memproduksi nata de coco sebagai usaha rumahan sehingga bisa menambah perekonomian bagi keluarga.

Peluang usaha nata de coco yang sangat bagus karena: .bahan baku untuk membuat nata mudah diperoleh (memanfaatkan air kelapa darinpara pedagang kelapa dan petani kopra ), sedangkan air kelapa yang baik untuk digunakan sebagai bahan baku pembuatan nata de coco adalah air dari kelapa yang sudah tua., poses pembuatan nata de coco tergolong mudah. Ini bisa dilakukan oleh industri skala rumah tangga bahkan setiap orang bisa membuat dengan modal yang tidak begitu besar,alat - alat untuk produksi mudah di dapatkan dan harga dari alat produksi juga murah . Terlebih sudah ada tindak lanjut dari proses pendampingan ini bahwa ada beberapa Toko yang sudah siap menerima hasil olahan nata de coco dari para Anggota Fatayat NU Kecamatan Metro Utara untuk ikut memasarakan dan membeli produk yang sudah siap dipasarkan.

Sampai sekrang permintaan dari perusahaan pengolahan nata de coco terus meningkat dari tahun ke tahun dan para pembuat nata masih kewalahan untuk memenuhi permintaan 
perusahaan. Karena Nata de coco merupakan makanan yang tinggi kandungan seratnya.Merupakan industry yang ramah lingkungan. Usaha nata de coco tidak menimbulkan pencemaran dengan pengolahan limbah yang baik.

Sedangkan Nata de Coco memiliki banyak manfaat bagi tubuh diantaranya adalah : Mengatasi sembelit (Serat yang terkandung dalam nata de coco terdiri dari selulosa, hemiselulosa, lignin, dan serat larut air. Kandungan serat yang sangat tinngi pada nata de coco bermanfaat memperlancar proses pencernaan dan proses pembuangan kotoran sisa dari dalam tubuh. Proses ini terjadi karena serat akan menyerap cairan dalam usus besar, sehingga kotoran bisa keluar dengan lancer, meningkatkan imunitas tubuh), Kandungan

vitamin $B$, khususnya vitamin B1, B2, dan vitamin $C$ pada nata de coco sangat bermanfaat untuk meningkatkan imunitas

tubuh. Manfaat air kelapa untuk meningkatkan kekebalan tubuh juga disebabkan air kelapa mengandung beberapa nutrisi seperti niasin, riboflavin, thiamin, piridoksin dan asam folat.,Aman untuk penderita diabetes (Nata de coco memiliki kandungan kolesterol yang rendah, sehingga mengonsumsi produk ini tidak mengganggu sirkulasi darah dan tidak memengaruhi konsentrasi gula di dalam darah. Asupan kalori yang rendah juga akan mengurangi sekresi insulin. Yang penting, nata de coco dikonsumsi dalam takaran yang sesuai dan dilakukan dengan cara yang benar ), membantu program diet ,kandungan serat dalam nata de coco dapat membantu mensukseskan proses diet karena mampu mengikat air dan menyerap karbohidrat dengan baik. Serat dalam nata de coco juga membuat perut terasa kenyang lebih lama, karena menunda proses pengosongan lambung

\section{SIMPULAN}

Pendanpingan ini dapat meningkatkan pengetahuan dan ketrampilan para anggota Fatayat NU Kecamatan Metro Utara dalam mengolah limbah air kelapa menjadi olahan nata de coco sehingga baik para anggota Fatayat NU Kecamatan Metro Utara memiliki tambahan pengahsilan juga Fatayat NU Kecamatan Metro Utara memiliki dana tambahan dari para anggota untuk kegiatankegiatan Fatayat NU Kecamatan Metro Utara.

Pohon kelapa adalah salah satu jenis tanaman yang tumbuh subur di Negara Indonesia karena pohon kelapa sangat cocok dengan iklim yang ada diIndonesia, Tanpa perawatan yang khusus pohon kelapa bisa tumbuh subur dimana saja. Pohon kelapa ini memiki manfaat yang sangat banyak mulai dari daunnya, batang pohon sampai buah yang dihasilkan. Manfaat dari buah kelapa sangatlah banyak, Diantaramya adalah airnya untuk menghilangkan dahaga, daging buah kelapa yang masih muda dapat dibuat sebagai campuran minuman atau makanan sedangkan daing buah yang sudah tua dapat dibuat sebgai 
santan kelapa sebagai bahan campurn dalam membuat makanan atau minuman.

\section{DAFTAR RUJUKAN}

$\begin{array}{cccr} & \text { Viral Nata } & \text { De Coco Mengandung } \\ \text { Plastik, Ini } & \text { Penjelasan } & \text { BPOM. }\end{array}$ "Kompas.com," t.t. https://sains.kompas.com/read/2019/12/08/190 400123/viral-nata-de-coco-mengandungplastik-ini-kata-badan-pom.

Mandey, Lucia C, Jenny E A Kandou, dan Tineke $M$ Langi. "Pengembangan Produksi Selulosa Nata Sebagai Produk Kesehatan dari Limbah Air Kelapa dengan Menggunakan Bakteri Acetobacter xylinum" 4, no. 2 (2016): 8.

Nurhasanah, Laila Aspita, Mulyono, Rilyanti Mita, dan Noviany. (2017)."Pelatihan Pembuatan Nata de Coco Secara Higienis bagi Masyarakat Desa Fajar Baru Lampung Selatan.” Lampung: Universitas Lampung.

Nata de Coco. "Peluang Usaha Nata de Coco," 6 Maret 2013. http://buhemohemo123.blogspot.com/2013/.

Viral Nata De Coco Mengandung Plastik, Ini Penjelasan BPOM. "Tempo.co," t.t. https://bisnis.tempo.co/read/1281619/viralnata-de-coco-mengandung-plastik-inipenjelasan-bpom. 